\title{
LOGICAL FRAMEWORK MATRIX (LFM) IN MALAYSIA GOVERNMENT PROJECT PLANNING
}

\author{
Norhanim Zakaria, Nurul Izzati Muhamed Yusuff, Azlan Shah Ali*, Umi Kalsum Zolkafli \\ Centre for Construction, Building and Tropical Architecture, Faculty of Built Environment, University of Malaya, \\ 50603 Kuala Lumpur \\ E-mail:*asafab@um.edu.my
}

\begin{abstract}
The Malaysian Government adopted the Logical Framework Approach (LFA) as a crucial project management tool in implementing Outcome Based Approach (OBA) for public projects in 2009 via the issuance of the Guideline for Planning and Preparation of Programs and Projects Development 1/2009. The guideline was issued by the Economic Planning Unit (EPU) of the Prime Minister's Department (JPM) (also known as Ministry of Economic Affairs (MEA) since 2018), Malaysia. The Logical Framework Matrix (LFM) has been suggested as a key tool for project appraisal. However, there are some cases where the LFM has not been appropriately utilized by the ministries and agencies. This paper therefore presents the frequent failings of LFM and practical issues in the participatory approach of LFA process, which contribute to the LFM produced. Findings from the study conducted via document review and interview confirmed that frequent failings of LFM and practical issues occur in preparing LFM in Malaysia Government project planning. Three (3) measures to overcome the existing challenges as well as in reducing existing gaps were identified to include knowledge management, enforcement and format.
\end{abstract}

Keywords : Project Planning, Logical Framework Approach (LFA), Logframe (LF), Practical Issues, Frequent Failings

\section{INTRODUCTION}

The excellence of project planning is a key factor in every successful project (Dvir \& Lechler, 2004) and it is proven by a great number of applied studies who identified planning as one of the major contributors to project success (Dvir \& Lechler, 2004; Murphy, Baker \& Fisher, 1974; Pinto \& Slevin, 1987). Project development planning requires a planner to endlessly dictate the immediate and eventual outcome of a project as well as the project impact. Continuous project monitoring route for project completion is important to ensure project success. Hence, project planning should be established in order to facilitate during-project monitoring. Radujkovic and Sjekavica (2017) specified that the task of managing project involves planning, organising, monitoring and controlling all aspects of the project. In accordance to this, project management tools need to be identified during planning stage and the knowledge, skills and techniques available can be applied by the particular project manager in the effort of making sure the project desires are met.

Looking towards outcome-based decision making, in the year of 2009, the Malaysian Government adopted the Logical Framework Approach (LFA) as a project management tool in implementing Outcome Based Approach (OBA) for public projects planning. Logical Framework Matrix (LFM), a product of LFA is a referral document (softcopy) for project approvals by the appraisals' officers in Economy Planning Unit, Prime Minister's Department (JPM). However, it has not been appropriately utilized by the ministries and agencies. Document review method has been applied on three (3) types of public documents such as; Guideline for Planning and Preparation of Programs and Projects Development 1/2009 by the Economic Planning Unit (EPU) of the Prime Minister's Department (JPM), Malaysia. 


\section{LITERATURE REVIEW}

LFA is a tool to assist project design and appraisal (Crawford \& Bryce, 2003). It is a bottom-up approach that always begins by listening to the target group's own assessment of their situation and needs (Ortengren, n.d.) and has been used as project design and evaluation tool in United States Agency for International Development (USAID) (an America organization) in early 1969 (Practical concept, 1978; Sartorius, 1996; Couillard, Garon \& Riznic, 2009). Like other methods of Results-Based Management (RBM) such as Balance Scorecard, SWOT analysis, Total Quality Management (TQM) and Prince, LFA is one of them.

LFA is a comprehensive planning model in contrast with other methods (Ortengren, n.d.) as it creates relevant and feasible plans that lead to sustainable outcomes. A product of the LFA is the LFM, which is defined as a project brief document, which provides a skeleton of the strategic features of the aims of a project (Nuthu, 2013). Logframe (LF) matrix or LFM, a product of LFA, has significant potential. LFM makes it possible to summarize a complex project into a one- or two-page document, making it clear for all stakeholders to understand the logic behind the intervention (Nuthu, 2013). In the process of preparing the LFM, planners could focus on strategic thinking while they are scrutinising the project objectives as well as the risk that project is going to encounter in the construction phase later (Buttigieg, et al., 2016; Sandra, et al. 2016). Throughout the process, LFM also helps in capacity-building among planners. LFM that presents the overall concept of a particular project could be treated as an organisational planner and tool for control.

Since the Malaysian Government introduced the Outcome Based Approach (OBA) for public projects in 2009, LFA has been increasingly adopted as a tool of managing project planning by the Ministry/Agency. The Malaysian Government has introduced Guideline for Planning and Preparation of Programs and Development Projects since 4th December 2009 to nurture the planning officers practicing OBA in project planning (EPU, 2009). There are several methods of planning and providing programs and projects outlined in the guideline, in particular the LFA (Jaapar, Maznan \& Zawawi, 2012) and Project Cycle Management (PCM) (EPU, 2009). According to the guideline, Project Preparation Using LFA comprises of three phases; Phase 1 - Project Identification \& Preparation; Phase 2 - Pre-Feasibility Study; and Phase 3 - Evaluation, Selection and Approvals. This initiative promoted by the Malaysian Government was; to ensure ministries and agencies plan projects that could provide value for money; to ensure that the shortcomings of planning and past project implementation are not repeated; and to assist ministries and agencies in drafting their respective programs and projects contribute to the achievement of targeted outcomes.

This study will specifically review the planning officers' (from Ministry / Agency) perspective on the issues and challenges they encountered in producing the LFM of each project with more focus on Phase 1 of the guideline. The structure of LFM practiced in Malaysian Government project planning is illustrated in Figure 1. However, there have been cases where the LFM has not been appropriately utilized by the ministries and agencies. Ministry or Agency possibly will use the LFA and LFM in different ways (i.e. LFA producing a LFM - the ideal type described in the various text books, manuals and guidelines; LFM without LFA - a matrix is produced at some stage during planning but without any participatory process; or not at all) (Bakewell \& Garbutt, 2005, as cited in Las Casas \& Scorza, 2016).

In construction projects, coordination amongst the consultants and contractors are rather critical in ensuring smooth flow of project information. Therefore, management of project needs platform and mechanism that could integrate the project key personals inputs. LFA is one of the approached uses the principles of Integrated Project Delivery (IPD), which the aims are to optimize project performance. This could be achieved through improving collaboration among project participants by continuous involvement of key project stakeholders (Hamid \& Carrie, 2019; Asma et al., 2016). By having IPD concept, it also would contribute in better cost control, accurate schedule and efficient project documentation (Elie et al. 2019).

Gasper (1999, 2000) (as cited in Ika \& Lytvynov, 2011) and Golini et al. (2018) stated that from past experiences, four (4) frequent failings of LFM have been identified to include; (i) 'logic-less frames'- logic is invented after a project has been designed; (ii) 'jamming'- too much into one diagram or oversimplifying; (iii) 'lack-frame'- LFM is normally too simple which omit dynamic phases of a project, even for simple project designs; (iv) 'lock-frame' - whereby programme learning and adaptation are blocked and tends to be fixed and not updated. It might be caused by the project team (Cracknell, 1989; Gasper, 2000). From literature, it has been stated that issues and problems of the participatory approach in LFA probably are major pitfalls in those failures in LFM 
(Gasper, 2000; European Integration Office, 2011). In accordance to that, the issues and problems of the participatory approach in LFA are probably the reasons why LFM submitted together with new project application to EPU JPM has not been comprehensive. Also, previous studies have reported that practical issues during LFA contribute to the pitfalls of LFM. Figure 2 shows the theoretical framework which can hold or support a theory (Costello, Donnellan \& Curley, 2013) for this study and it can be seen that the practical issues contribute to LFM frequent failings. Thus, this study aims to establish measures to overcome the existing challenges in preparing LFM in Malaysian Government project planning. The objectives of this study are:

i) to review the gaps that exist in preparing LFM in Malaysian Government project planning;

ii) to identify existing challenges in preparing LFM in Malaysian Government project planning; and

iii) to establish measures to overcome the existing challenges in preparing LFM in Malaysia Government project planning.

\begin{tabular}{|c|c|c|c|}
\hline $\begin{array}{l}\text { Project Description } \\
\text { (Intervention Logic) }\end{array}$ & $\begin{array}{c}\text { OVI (Objectively } \\
\text { Verifiable Indicators) }\end{array}$ & $\begin{array}{l}\text { MOV (Method of } \\
\text { Verification) }\end{array}$ & Assumptions \\
\hline Goal (1) & Indicators (8) & MOVs (9) & NA \\
\hline $\begin{array}{l}\text { Impact of development } \\
\text { contributed by the } \\
\text { project at national and } \\
\text { ministry. }\end{array}$ & $\begin{array}{l}\text { Measurable indicators } \\
\text { that will show } \\
\text { whether or not the } \\
\text { expected results (goal) } \\
\text { have been achieved. } \\
\text { Useable for evaluation. }\end{array}$ & $\begin{array}{l}\text { The means, methods } \\
\text { and sources by which } \\
\text { the key indicators (OVI) } \\
\text { will be recorded and } \\
\text { made available to project } \\
\text { management or those } \\
\text { evaluating project } \\
\text { performances (i.e. source } \\
\text { of information; project } \\
\text { reports, market and } \\
\text { production statistics, } \\
\text { financial records etc.) }\end{array}$ & \\
\hline $\begin{array}{c}\text { Purpose / Immediate } \\
\text { Objective / Component } \\
\text { Objectives (2) }\end{array}$ & Indicators (10) & MOVs (11) & Assumptions (7) \\
\hline $\begin{array}{l}\text { Expected outcome after } \\
\text { project completed. }\end{array}$ & $\begin{array}{l}\text { Measurable indicators } \\
\text { that will show } \\
\text { whether or not the } \\
\text { expected results } \\
\text { (outcome) have been } \\
\text { achieved after the } \\
\text { project completed. } \\
\text { Useable for evaluation. }\end{array}$ & $\begin{array}{l}\text { The means, methods } \\
\text { and sources by which } \\
\text { the key indicators (OVI) } \\
\text { will be recorded and } \\
\text { made available to project } \\
\text { management or those } \\
\text { evaluating project } \\
\text { performances (i.e. source } \\
\text { of information; project } \\
\text { reports, market and } \\
\text { production statistics, } \\
\text { financial records etc.) }\end{array}$ & $\begin{array}{l}\text { Conditions which could } \\
\text { affect the progress or } \\
\text { success of the project, } \\
\text { but over which the } \\
\text { project management has } \\
\text { no direct control. } \\
\text { (Between goals and } \\
\text { purpose) }\end{array}$ \\
\hline Outputs (3) & Indicators (12) & MOVs (13) & Assumptions (6) \\
\hline $\begin{array}{l}\text { The specific results or } \\
\text { tangible } \\
\text { products/services } \\
\text { produced } \\
\text { undertaking a series of } \\
\text { tasks/activities using } \\
\text { the project inputs which } \\
\text { is under control of } \\
\text { project management. }\end{array}$ & $\begin{array}{l}\text { Measurable indicators } \\
\text { for quantity and output } \\
\text { quality as well as the } \\
\text { duration of project } \\
\text { handover. } \\
\begin{array}{l}\text { during } \\
\text { monitoring } \\
\text { evaluation. }\end{array}\end{array}$ & $\begin{array}{l}\text { The means, methods } \\
\text { and sources by which } \\
\text { the key indicators (OVI) } \\
\text { will be recorded and } \\
\text { made available to project } \\
\text { management or those } \\
\text { evaluating project } \\
\text { performances (i.e. source } \\
\text { of information; project } \\
\text { reports, market and } \\
\text { production statistics, } \\
\text { financial records etc.) }\end{array}$ & $\begin{array}{l}\text { Conditions which could } \\
\text { affect the progress or } \\
\text { success of the project, } \\
\text { but over which the } \\
\text { project management has } \\
\text { no direct control. } \\
\text { (Between outputs and } \\
\text { purpose) }\end{array}$ \\
\hline Activities (4) & \multirow{2}{*}{\multicolumn{2}{|c|}{$\begin{array}{c}\text { Milestones specified in activity schedules and scope } \\
\text { of services. Work plans and management reports on } \\
\text { physical and financial progress (i.e. Work Plan, } \\
\text { Material and Equipment Plans, Human Resources } \\
\text { and Budget). }\end{array}$}} & Pre-Conditions (5) \\
\hline $\begin{array}{l}\text { Tasks and operations } \\
\text { carried out by project } \\
\text { personnel to transform } \\
\text { project inputs into } \\
\text { identified outputs. }\end{array}$ & & & $\begin{array}{l}\text { Conditions (if any) } \\
\text { attached to the } \\
\text { provision of aid are also } \\
\text { included (i.e.: no } \\
\text { objections from locals; } \\
\text { technology that required } \\
\text { is ready exist; budget } \\
\text { required already } \\
\text { available). }\end{array}$ \\
\hline
\end{tabular}

Figure 1: A LFM format used in Malaysian Government project planning (Source: EPU (2009); EPU (2010)) 


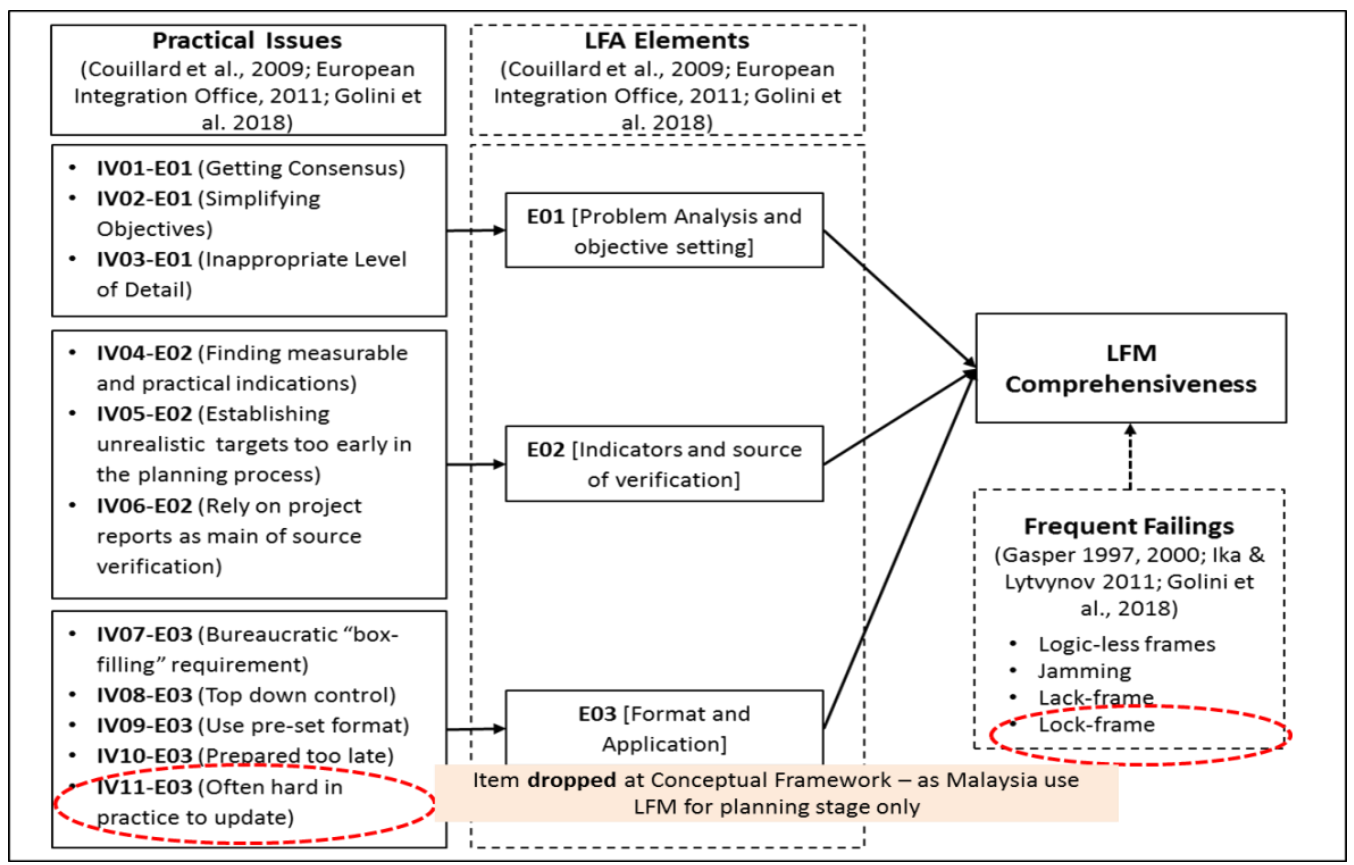

Figure 2: Theoretical Framework- Adapted from Gasper (2000); Crawford et al., (2003); Couillard et al., (2009); European Integration Office (2011); Ika et al., (2011) and Golini et al., (2018)

\section{METHODOLOGY}

This study utilised a qualitative approach as it allowed the researcher to enter the world of others and attempt to achieve holistic view of real-life phenomenon for LFM implementation in Malaysian Government project planning (Bloomberg \& Volpe, 2012; as cited in Mason, 1996). Deductive and inductive content analysis (Elo \& Kyngäs, 2008; Miles, Huberman \& Saldana, 2014) was used in getting input from the informants. To ensure the consistency and accuracy of data analysis carried out in this study, the codebook was developed (MacQueen, McLellan, Kay \& Milstein, 1998; Fonteyn, Vettese, Lancaster \& Bauer-Wu, 2008). Table 1 shows the description of research methodology applied in this research.

Table 1: Methodology Description

\begin{tabular}{|c|l|c|c|}
\hline No. & \multicolumn{1}{|c|}{ Objective(s) } & Method & Type of Analysis \\
\hline 1. & $\begin{array}{l}\text { To review the gaps that exist in preparing LFM in } \\
\text { Malaysian Government project planning }\end{array}$ & $\begin{array}{c}\text { Document } \\
\text { Review \& } \\
\text { Interview EPU } \\
\text { JPM (MEA) }\end{array}$ & $\begin{array}{c}\text { Document analysis / } \\
\text { Comparative analysis / } \\
\text { Validating analysis / } \\
\text { Inductive and Deductive } \\
\text { Content analysis }\end{array}$ \\
\hline 2. & $\begin{array}{l}\text { To identify existing challenges in preparing LFM } \\
\text { in Malaysian Government project planning }\end{array}$ & $\begin{array}{c}\text { Interview } \\
\text { (8 ministries, } \\
\text { EPU JPM } \\
\text { (MEA), } \\
\text { INTAN \& }\end{array}$ & $\begin{array}{c}\text { Deductive Content analysis } \\
\text { / Validating analysis }\end{array}$ \\
\cline { 2 - 2 } & $\begin{array}{l}\text { To establish measures to overcome the existing } \\
\text { challenges in preparing LFM in Malaysian } \\
\text { Government project planning }\end{array}$ & $\begin{array}{c}\text { Inductive Content analysis } \\
\text { / Validating analysis }\end{array}$ \\
\hline
\end{tabular}

\subsection{Document Review}

Goodstadt (2005) stated that project evaluation is actually a "flip side" of project planning and referring to ICU (2012), project outcome evaluation might be done by re-evaluating the information specified in the project plan (LFM document) submitted during project planning stage. ICU (2017) reported lowest score (\%) for 'Methodology Compliance Parameter' was 'Data Analysis with remarks of no unit of analysis, do not apply 
Specific, Measurable, Achievable, Realistic, Timeliness (S.M.A.R.T.) principle, no target, no comparison before and after project completion' with the score of only 78.7\%. Meanwhile for 'Outcome Parameter' was 'Development of Performance Indicator with remarks of confused in determining output and outcome' with only $85.2 \%$. Hence, document review on LFM document will be more in depth focusing on column 1 and 2. Document review format is as illustrated in Figure 3 and assessment criteria to determine comprehensiveness' level of the LFM document (sample) is described in Figure 4.

\begin{tabular}{|c|c|c|c|}
\hline \multicolumn{1}{|c|}{ Column 1 } & \multicolumn{1}{c|}{ Column 2 } & Column 4 \\
\hline \hline $\begin{array}{c}\text { Project Description } \\
\text { (Intervention Logic) }\end{array}$ & $\begin{array}{c}\text { OVI } \\
\text { (Objectively } \\
\text { Verifiable Indicators) }\end{array}$ & $\begin{array}{c}\text { MOV } \\
\text { (Method of } \\
\text { Verification) }\end{array}$ & Assumptions \\
\hline Goal (1) & Indicators (8) & MOVs (9) & NA \\
\hline $\begin{array}{c}\text { Purpose / Immediate } \\
\text { Objective / Component } \\
\text { Objectives (2) }\end{array}$ & Indicators (10) & MOVs (11) & Assumptions (7) \\
\hline Outputs (3) & Indicators (12) & MOVs (13) & Assumptions (6) \\
\hline Activities (4) & $\begin{array}{c}\text { Milestones specified in activity schedules } \\
\text { and scope of services. Work plans and } \\
\text { management reports on physical and } \\
\text { financial progress }\end{array}$ & Pre-Conditions (5) \\
\hline
\end{tabular}

Figure 3: Document review format

\begin{tabular}{|c|c|c|c|c|}
\hline $\begin{array}{l}\text { Assessm ent } \\
\text { Criteria }\end{array}$ & Column 1 & Column 2 & Column 3 & Column 4 \\
\hline Goal & $\begin{array}{l}\text { Project goal setting } \\
\text { can be determine } \\
\text { after } 5 \text { years project } \\
\text { completion (impact } \\
\text { characteristic) }\end{array}$ & \multirow{3}{*}{$\begin{array}{l}\text { - has an } \\
\text { analytical unit } \\
\text { - adhere } \\
\text { S.M.A.R.T. } \\
\text { principle } \\
\text { - realistic target } \\
\text { - comparison } \\
\text { before and after } \\
\text { project } \\
\text { completion }\end{array}$} & $\begin{array}{l}\text { Information } \\
\text { disclosed }\end{array}$ & $\mathrm{NA}$ \\
\hline $\begin{array}{l}\text { Purpose / } \\
\text { Immediate } \\
\text { Objective / } \\
\text { Component } \\
\text { Objectives }\end{array}$ & $\begin{array}{l}\text { The project } \\
\text { purpose/objective } \\
\text { adhere to the } \\
\text { principle of } \\
\text { S.M.A.R.T } \\
\text { (outcome } \\
\text { characteristic and } \\
\text { can be achieve after } \\
2-5 \text { years project } \\
\text { completion }\end{array}$ & & $\begin{array}{l}\text { Information } \\
\text { disclosed }\end{array}$ & $\begin{array}{l}\text { Information } \\
\text { disclosed }\end{array}$ \\
\hline Outputs & $\begin{array}{l}\text { Tangible products / } \\
\text { services (outputs or } \\
\text { results) }\end{array}$ & & $\begin{array}{l}\text { Information } \\
\text { disclosed }\end{array}$ & $\begin{array}{l}\text { Information } \\
\text { disclosed }\end{array}$ \\
\hline Activities & $\begin{array}{l}\text { Describe } \\
\text { 'indicative' sets of } \\
\text { activities (required } \\
\text { to deliver each } \\
\text { output) }\end{array}$ & \multicolumn{2}{|c|}{$\begin{array}{l}\text { *Describes / Plan activities relevant to } \\
\text { the project nature }\end{array}$} & $\begin{array}{l}\text { Information } \\
\text { disclosed }\end{array}$ \\
\hline $\begin{array}{l}\text { Assessment } \\
\text { Approach }\end{array}$ & $\begin{array}{l}\text { Likert scale: } \\
\text { (3)-Good } \\
\text { (2)-Fair } \\
\text { (1)-Poor }\end{array}$ & $\begin{array}{l}\text { *Likert scale: } \\
\text { (3)-Good } \\
\text { (2)-Fair } \\
\text { (1)-Poor }\end{array}$ & $\begin{array}{l}\text { Dichotomous } \\
\text { Scales: } \\
\text { (2) - Yes } \\
\text { (1) }-\mathrm{No}\end{array}$ & $\begin{array}{l}\text { Dichotomous } \\
\text { Scales: } \\
\text { (2) - Yes } \\
\text { (1) - No }\end{array}$ \\
\hline
\end{tabular}

Figure 4: Content analysis criteria for determining the LFM Comprehensiveness 


\subsection{Interview}

The purpose of the interview was to validate findings from document review and to identify the existing challenges or practical issues encountered by planning officers as well as measures to overcome those challenges in preparing LFM in Malaysian Government project planning. Several structured interview sessions were conducted with selected government officers involved in Malaysian Government project management specifically in engaging with LFM implementation at project planning stage. The selection of informants was through both purposive and convenience sampling technique and contact availability among the informant (Kothari, 2004; Tongco, 2007; Etikan et al; 2016). It was difficult to determine the number of informants in this study. However, the number of informants were derived after data saturation was achieved. This was determined by observing the data collected from further informants does not provide any repetitive information. Saturation can be reached after interviewing two (2) to ten (10) participants (informants) (Boyd, 2001; as cited in Michalak \& Ristino, 2013). Once this stage was reached, the number of informants required for this interview was adequate. Figure 4 steered the construction of interview questions for this study.

\subsection{Data Analysis Process}

The data analysis process started with LFM documents review. Comparative analysis throughout the box filling of each sample was studied. Comprehensiveness' level of box filling categorized into three (3) parameters; '1 - Poor'; '2 - Fair', and; ' 3 - Good'. Content analysis also applied in this study as to achieve the first objective. In the context of assessing the box filling in columns 1 and 2, the same approach was convenient. Multiple sources of evidence helped in validating findings (Denzin \& Lincoln, 2018). To validate the findings, structured interview were carried with selected individuals.

The interview or focus group interview conducted purposively to validate findings from the document review method. Grounded theories of identified ten (10) practical issues (independent variables) from the literature were tested. Inductive content analysis was useful to gather input from the informants regard their opinion, suggestion or recommendation of measures to overcome the existing challenges in preparing the LFM and to enhance the implementation of LFM in Malaysia Government project planning.

Examples of questions asked to respondents are as follows:

- Do Ministry / Agency attach the LFM together with their new project application to EPU JPM? The guideline is compliance or not has been determined by using below quotes $(\mathrm{Q})$ :

- What is the definition of comprehensive and reliable LFM for project approval? Comprehensive is defined by the Informant as below quotes $(\mathrm{Q})$ :

- Question A01 (1.2): If 'Yes', is that LFM comprehensive and reliable

- Question A01 (1.3): Do you met below failure in LFM document? (i.e.: logic-less frames - invented after project has been designed; jamming - oversimplify; lack-frames - too simple) Answer using Likert scale; (5) - Always; (4) - Very Often; (3) - Sometimes; (2) - Rarely; (1) - Never

\section{FINDINGS AND DISCUSSION}

There had been indicated that some steps inside the theorization and assessment required for evaluating LFA itself. However, up till now, there is no study on it as well as LFM in Malaysia Government project planning. Some of the significant findings derived from the study as discuss below:

\subsection{Gaps existence in preparing LFM}

Frequent failings determined by document review and validated by interview indicated that gaps exist in preparing the LFM. Method and data source triangulation were applied in this study to ensure the findings are valid and reliable. Out of sixteen (16) multi-documents (LFM document), nine (9) were successfully reviewed and re-assessed by the appraisal officers (informants) involved in project appraisal in EPU JPM. This activity (document review) subject to the availability of related officers in EPU JPM, gave response rate of $56.3 \%$.

The document review was done using two (2) different scales (Likert scale and Dichotomous scales) separately for both column $1 \& 2$ and column $3 \& 4$. Dichotomous scales have been used for column $3 \& 4$ as to avoid bias. By using content analysis approach, with the guidance of criteria in determining the LFM comprehensiveness 
described in Figure 4, the average of total score (mean) in each box for all nine (9) multi-documents are illustrated in Figure 5.

\begin{tabular}{|c|c|c|c|c|}
\hline Assessment Criteria & Column 1 & Column 2 & Column 3 & Column 4 \\
\hline Goal & (1) 2.50 & (8) $\quad 2.70$ & (9) 2.00 & \\
\hline $\begin{array}{c}\text { Purpose / Immediate } \\
\text { Objective / Component } \\
\text { Objectives }\end{array}$ & $\begin{array}{ll}\text { (2) } & \\
& 2.10\end{array}$ & $\begin{array}{ll} & \\
& (10) \\
& \\
& \end{array}$ & $\begin{array}{ll}(11) & \\
& 1.80\end{array}$ & 1.80 \\
\hline Outputs & (3) 2.00 & (12) 2.10 & $\begin{array}{ll}\text { (13) } & \\
& 1.80\end{array}$ & $\begin{array}{ll}\text { (6) } & 1.70\end{array}$ \\
\hline Activities & $\begin{array}{ll}\text { (4) } & \\
& 2.20\end{array}$ & \multicolumn{2}{|c|}{$* 2.40$} & $\begin{array}{ll}\text { (5) } & \\
& 1.40\end{array}$ \\
\hline Comparable Value & $\begin{array}{l}\text { Likert scale: } \\
\text { (3)-Good } \\
\text { (2)-Fair } \\
\text { (1)- Poor }\end{array}$ & $\begin{array}{l}\text { *Likert scale: } \\
\text { (3)- Good } \\
\text { (2)-Fair } \\
\text { (1)-Poor }\end{array}$ & $\begin{array}{l}\text { Dichotomous } \\
\text { Scales: } \\
(2)-\text { Yes } \\
(1)-\text { No }\end{array}$ & $\begin{array}{l}\text { Dichotomous } \\
\text { Scales: } \\
(2)-\text { Yes } \\
\text { (1) - No }\end{array}$ \\
\hline
\end{tabular}

Figure 5: Average Score Value (Mean) Overview of all 9 multi-documents (LFM document) (Level of Comprehensiveness in each box in LFM)

However, in order to make the average scores (mean) for all columns so they are comparable to each other, the scores for each box were transformed into RII. Moreover, it will also be useful in comparing the findings by project's category. The formula below was used for the calculation of the RII (Badu, Owusu-Manu, Edwards, Adesi \& Lichtenstein, 2013):

where,

$$
\mathrm{RII}=\frac{\sum W}{A * N}
$$

W - weighting given to each value given by the appraisal officers (informants) for their projects (physical and non-physical) and ranges from 1 to 3 (for column 1 and 2); 1 or 2 (for column 3 and 4);

A - higher response integer ( 3 for column 1 and 2; 2 for column 3 and 4); and

$\mathrm{N}$ - total number of projects (physical and non-physical).

Figure 6 shows the overview of RII for each box for all the LFM documents (projects) that have been reassessed and it displays the level of box filling in column 4 (Assumptions) partly affecting the level of box filling in column 1 (Project Description) as they are related to each other (EPU, 2010).

\begin{tabular}{|c|c|c|c|c|}
\hline Assessment Criteria & Column 1 & Column 2 & Column 3 & Column 4 \\
\hline Goal & (1) $\begin{array}{c}0.83 \\
\\
\leftarrow--\end{array}$ & (8) 0.90 & $\begin{array}{ll}\text { (9) } & \\
& 1.00\end{array}$ & \\
\hline $\begin{array}{c}\text { Purpose / Immediate } \\
\text { Objective / Component } \\
\text { Objectives }\end{array}$ & (2) $\begin{array}{l}0.70 \\
\Leftrightarrow===:-\square\end{array}$ & $\begin{array}{r}(10) \cdots \\
0.67 \\
0\end{array}$ & $(11)$ & $=\Rightarrow 0.90$ \\
\hline Outputs & (3) 0.67 & (12) 0.70 & & $=\Rightarrow 0.85$ \\
\hline Activities & (4) 0.73 & $(14)^{\cdots \cdots}$ & & $\Rightarrow=0.65$ \\
\hline
\end{tabular}

Figure 6: Relative Importance Index (RII) for multi-documents (all project type) (Level of Comprehensiveness in each box in LFM)

Figure 7 shows the values of RII for each box in different category of physical project and non-physical project and it suggests that, column 3 (Method of Verification (MOV), RII=0.92) ranked first as an influential 
factor to the comprehensiveness' level of LFM. This followed by column 4 (Assumptions, RII=0.80). Then, column 1 (Project Description) and column 2 (Objectively Verifiable Indicators) ranked third and fourth respectively. In short, it can be seen that the index for all columns are above 0.70 exclude the index for column 2 $(\mathrm{RII}=0.69)$ for multi-document in the category of non-physical project.

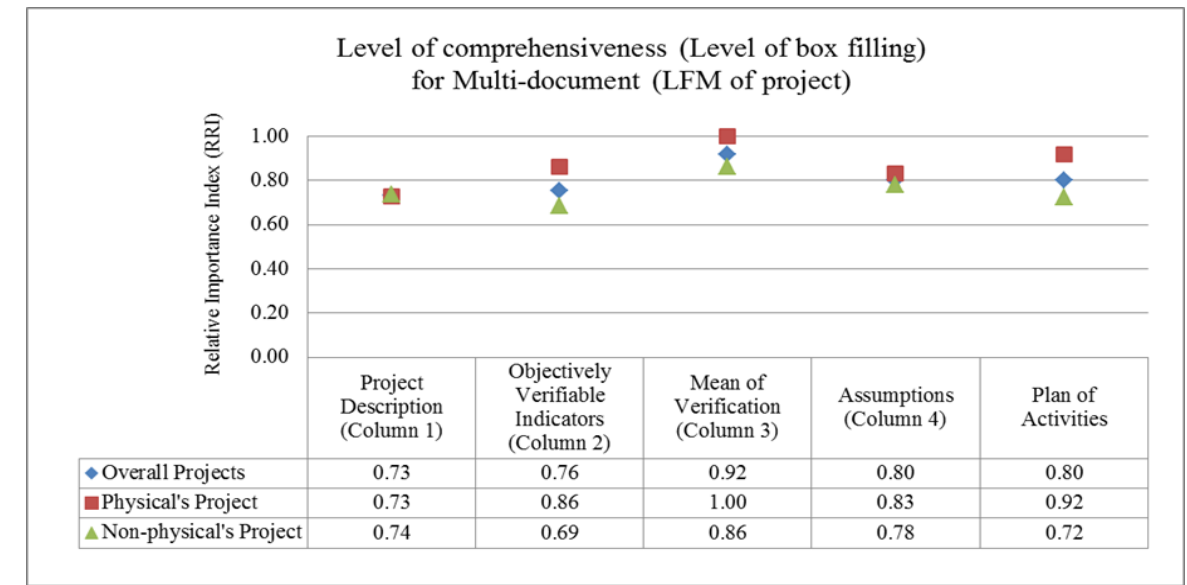

Figure 7: Relative Importance Index (RII) for multi-documents (Level of Comprehensiveness for each column in LFM)

Gaps exist in providing a comprehensive and reliable LFM probably due to inaccurate information and not complying with the S.M.A.R.T. principle, which ultimately affects the quality of LFM. Right information place in wrong box possibly due to lack of knowledge, skills and experience by the project planners. Frequent failings such as "logic-less frames" which the LFM invented after the project has been designed seemed not to be reaffirmed during interview session with EPU, JPM as they were unable to determine whether the LFM is invented after the project has been designed or not. However, it emerged from the interview session with INTAN when the informants did mention about "Ministry / Agency do reverse-engineering in preparing LFM". Four (4) top ranked challenges identified by the project planners during preparing LFM for non-physical project like "limitation of time", "box filling requirement", "unrealistic target", and "developing indicators" appears to be one among the reasons why the LFM quality for samples in this study was just Fair.

\subsection{Challenges in preparing LFM}

Grounded theory of ten (10) variables of practical issues as described in Figure 8 were reaffirmed by the interview to have been encountered by the planning officers in Malaysian Government project planning and new issues emerged from the data gathered.

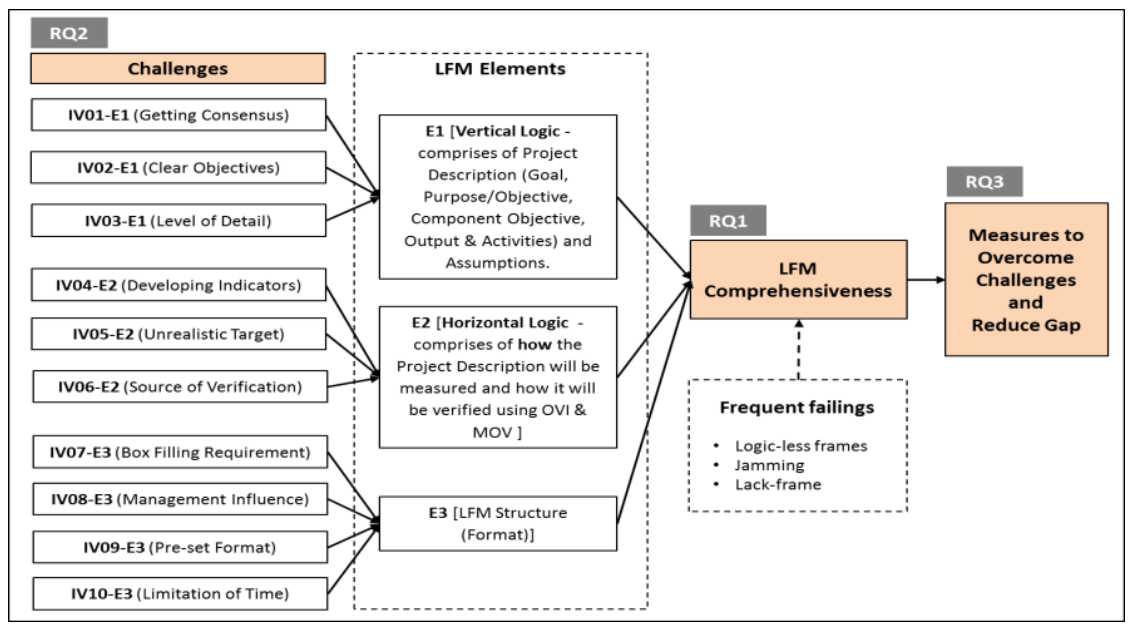

Figure 8: Ten (10) variables of practical issues encountered by the planning officers in Malaysia Government

project planning 
In identifying the highest frequency of practical issues that occurred, the referential unit as a data unit (Cooper \& Schindler, 2014) has been applied in this analysis. However, the referential unit of Likert scales were then converted to Relative Importance Index (RII) to ensure the findings can be comparable between each other. Figure 9 illustrates the pattern of occurrences' index score between types of project (physical and non-physical) and Table 2 describes the occurrences' index score for all types of project (physical and non-physical).

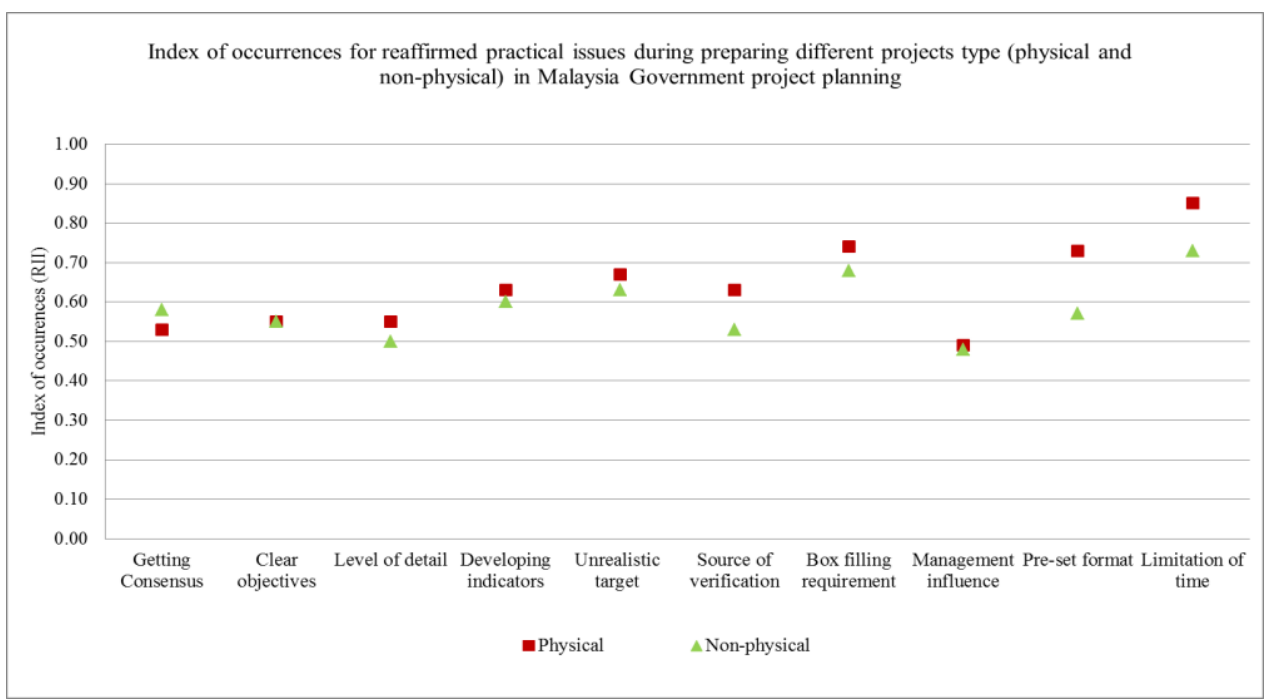

Figure 9: Index of occurrences for reaffirmed practical issues during preparing different projects type (physical and non-physical)

Three (3) new practical issues that emerged were; Knowledge; Skilled officer; and Experience. Table 2 which encompasses the occurrences' index score of the challenges in preparing the LFM shows the highest ranked contributor from the element of LFM Structure (Format) with RII=0.65. A challenge of "management influence" has less occurrence. Meanwhile, "pre-set format" occurs more in physical project possibly due to non-physical project having a different project nature and different type of target group compared to physical project, which is repeated and typical. "Limitation of time" to conduct LFA, LFM was invented after the project has been designed (logic-less frames) in which Ministry / Agency do reverse-engineering to prepare LFM. In short, it can be summarizing that challenges in participatory approach in LFA initiate LFM frequent failings.

Table 2: Occurrences index score for all types of project (physical and non-physical)

\begin{tabular}{|c|c|c|c|c|c|c|c|}
\hline \multirow{2}{*}{$\begin{array}{c}\text { LFM } \\
\text { Element }\end{array}$} & \multirow[t]{2}{*}{ Practical Issues } & \multicolumn{6}{|c|}{ Types of project } \\
\hline & & \multicolumn{2}{|c|}{$\begin{array}{c}\text { Physical \& Non- } \\
\text { physical }\end{array}$} & \multicolumn{2}{|c|}{ Physical } & \multicolumn{2}{|c|}{ Non-physical } \\
\hline \multirow{4}{*}{$\begin{array}{l}\text { LFM } \\
\text { Structure } \\
\text { (Format) }\end{array}$} & Limitation of time & 0.78 & \multirow{4}{*}{$\begin{array}{c}0.65 \\
\text { (average) }\end{array}$} & 0.85 & \multirow{4}{*}{$\begin{array}{c}0.70 \\
\text { (average) }\end{array}$} & 0.73 & \multirow{4}{*}{$\begin{array}{c}0.61 \\
\text { (average) }\end{array}$} \\
\hline & $\begin{array}{l}\text { Box filling } \\
\text { requirement }\end{array}$ & 0.69 & & 0.74 & & 0.68 & \\
\hline & Pre-set format & 0.67 & & 0.73 & & 0.57 & \\
\hline & $\begin{array}{l}\text { Management } \\
\text { influence }\end{array}$ & 0.48 & & 0.49 & & 0.48 & \\
\hline \multirow{3}{*}{$\begin{array}{l}\text { Horizontal } \\
\text { Logic }\end{array}$} & Unrealistic target & 0.60 & \multirow{3}{*}{$\begin{array}{c}0.58 \\
\text { (average) }\end{array}$} & 0.67 & \multirow{3}{*}{$\begin{array}{c}0.64 \\
\text { (average) }\end{array}$} & 0.63 & \multirow{3}{*}{$\begin{array}{c}0.59 \\
\text { (average) }\end{array}$} \\
\hline & $\begin{array}{l}\text { Developing } \\
\text { indicators }\end{array}$ & 0.58 & & 0.63 & & 0.60 & \\
\hline & $\begin{array}{l}\text { Source of } \\
\text { verification }\end{array}$ & 0.57 & & 0.63 & & 0.53 & \\
\hline \multirow{3}{*}{$\begin{array}{l}\text { Vertical } \\
\text { Logic }\end{array}$} & Getting Consensus & 0.53 & \multirow{3}{*}{$\begin{array}{c}0.52 \\
\text { (average) }\end{array}$} & 0.53 & \multirow{3}{*}{$\begin{array}{c}0.54 \\
\text { (average) }\end{array}$} & 0.58 & \multirow{3}{*}{$\begin{array}{c}0.54 \\
\text { (average) }\end{array}$} \\
\hline & Clear objectives & 0.52 & & 0.55 & & 0.55 & \\
\hline & Level of detail & 0.52 & & 0.55 & & 0.50 & \\
\hline
\end{tabular}




\subsection{Measures to overcome existing challenges preparing LFM}

Adopting inductive content analysis approach and the qualitative data unit defined as syntactical unit, the feedback or response obtained from the informant was transcribed and coded.

Thirteen (13) codes emerged, which include: Continuous training; Enforcement; Format; Refresher course; Project application timeline; Management influence; Referral tools for evaluation; Simplify the process; Training participants; Awareness, Promote shadow ceiling; \& User manual. All codes had been repeatedly mentioned by the informants, more than two (2) times and reached saturation requirements (Boyd, 2001) (as cited in Michalak et al., 2013). Then, the codes were categorized into themes. Nadler et al. (2003) discussed that training can results abilities to the individual and it's an important part of knowledge management process. Codes such as "continuous training", "refresher course", "training participants" and "awareness" has been categorized and put into a theme of Knowledge Management. Scrutinising the pattern of codes that emerged, the codes were then made into five (5) categorized: A-Knowledge Management \& Enforcement; B-Knowledge Management \& Format; C- Enforcement \& Format; D- Knowledge Management; E-Format; and F-Null. Mapping activity, which involved sub-measures (codes), measures' category and challenges in a matrix form was then conducted. Table 3 shows the results of measures' category to overcome challenges in preparing LFM according to the LFM elements.

Figure 10 was then established, which symbolizes the mediated relationship in achieving a comprehensive LFM. Meanwhile, Figure 11 represents the problem-solving model to overcome challenges in preparing LFM. The recommended model could aid in reducing the gaps that exist in preparing the LFM in Malaysian Government project planning. The black-bold arrows indicates that the process of LFA must be completed by the project planners in producing LFM; and the blue color at the 3rd layer of the box displays the challenges that might be encountered by the project planners while preparing the LFM and the 2nd layer of the box indicated by light blue color represents the third proposed variable (mediating variable), which comprises of; Knowledge Management, Enforcement and Format that will potentially help the project planners in handling the existing challenges as well as reducing the gaps that exist in preparing LFM in Malaysian Government project planning.

Table 3: Measures' category to overcome challenges in preparing LFM according to the LFM elements

\begin{tabular}{|c|c|c|c|c|c|c|}
\hline \multirow[t]{2}{*}{ LFM Elements } & \multirow{2}{*}{$\begin{array}{l}\text { Grounded Theory } \\
\text { (Practical Issues) }\end{array}$} & \multicolumn{5}{|c|}{$\begin{array}{l}\text { Measures' category to overcome challenges in } \\
\text { preparing LFM (Percentage, \%) }\end{array}$} \\
\hline & & $\mathbf{A}$ & B & $\mathbf{C}$ & D & $\mathbf{E}$ \\
\hline \multirow{4}{*}{$\begin{array}{l}\text { LFM Structure } \\
\text { (Format) }\end{array}$} & Limitation of Time & \multirow{4}{*}{38.0} & \multirow{4}{*}{29.3} & \multirow{4}{*}{6.6} & \multirow{4}{*}{19.5} & \multirow{4}{*}{6.6} \\
\hline & $\begin{array}{l}\text { Box Filling } \\
\text { Requirement }\end{array}$ & & & & & \\
\hline & Pre-set Format & & & & & \\
\hline & Management Influence & & & & & \\
\hline \multirow{3}{*}{$\begin{array}{l}\text { Horizontal } \\
\text { Logic }\end{array}$} & Unrealistic Target & \multirow{3}{*}{39.2} & \multirow{3}{*}{10.8} & \multirow{3}{*}{10.8} & \multirow{3}{*}{21.7} & \multirow{3}{*}{17.5} \\
\hline & Developing Indicators & & & & & \\
\hline & Source of Verification & & & & & \\
\hline \multirow[t]{3}{*}{ Vertical Logic } & Getting Consensus & \multirow{3}{*}{36.1} & \multirow{3}{*}{25.0} & \multirow{3}{*}{8.3} & \multirow{3}{*}{16.7} & \multirow{3}{*}{13.9} \\
\hline & Clear Objectives & & & & & \\
\hline & Level of Detail & & & & & \\
\hline
\end{tabular}




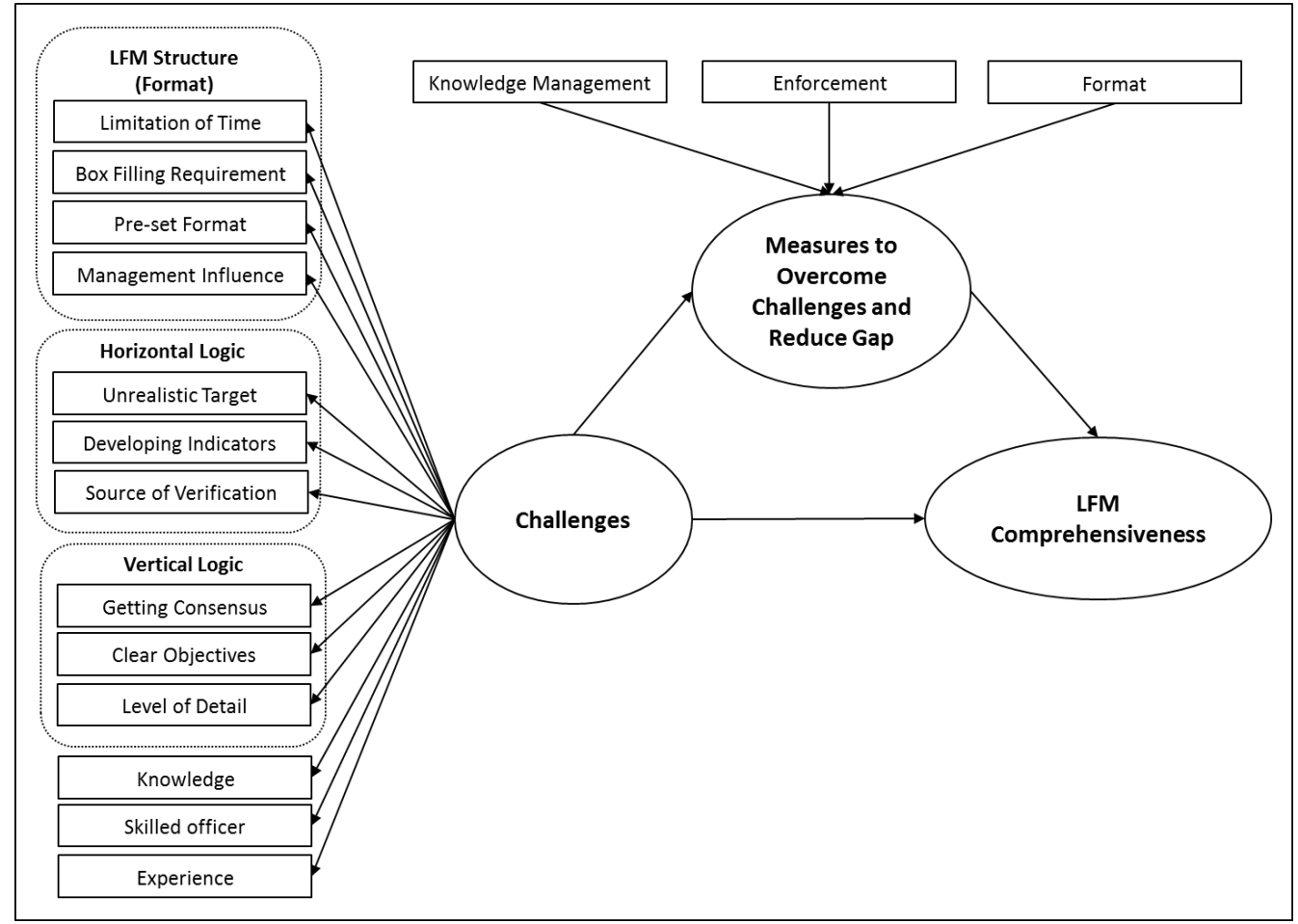

Figure 10: Preliminary framework in achieving LFM comprehensiveness in Malaysian Government Project Planning

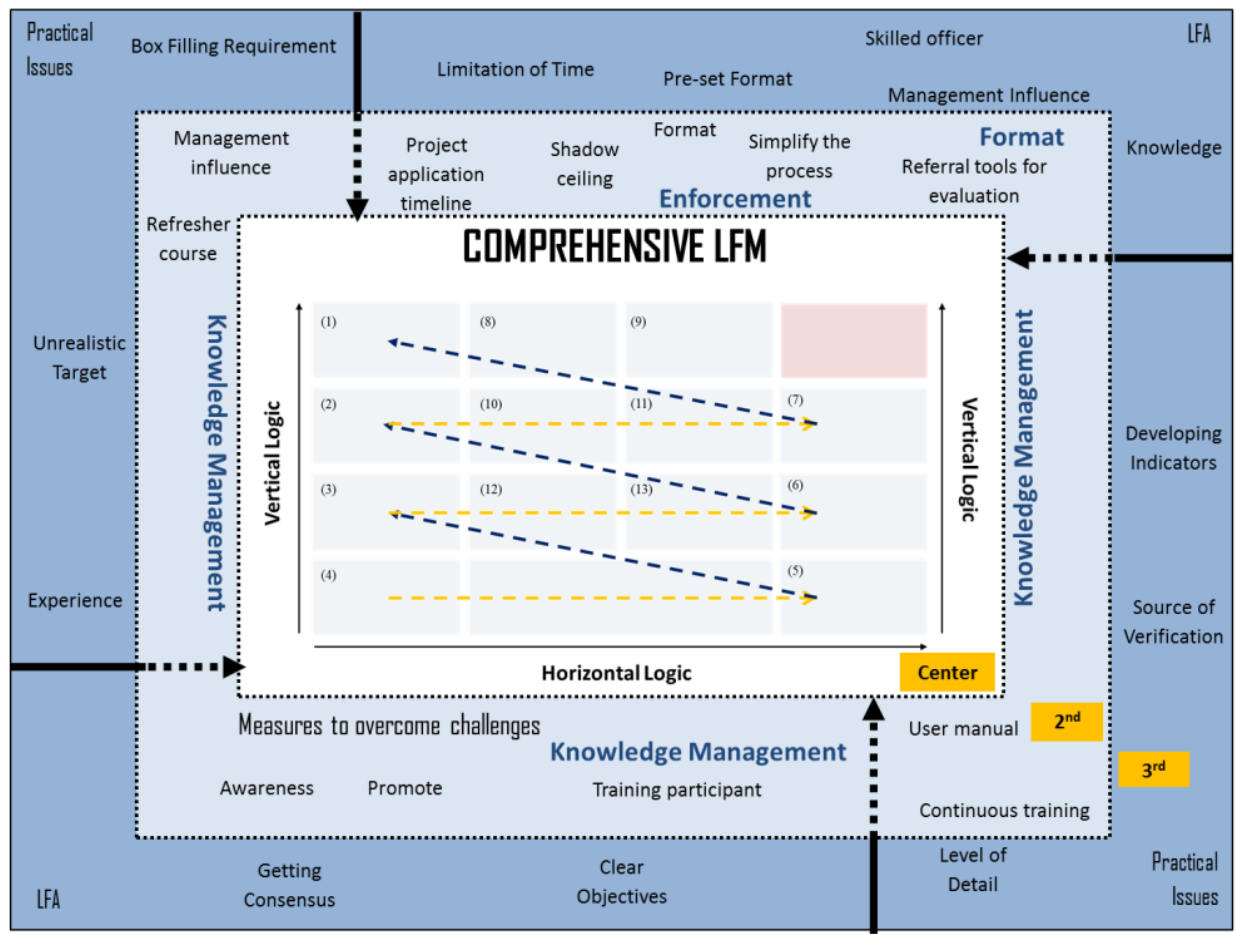

Figure 11: Problem solving model to overcome challenges and reduce gaps in preparing LFM in Malaysian Government project planning 
Examining the codes that emerged from the informants, two (2) highest ranked measures' category to overcome challenges were: Category A: Knowledge Management \& Enforcement; Category B: Knowledge Management \& Format. This is supported by Nguyen \& Mohamed (2011) who notes that the leader conducts an important influence the effectiveness of KM in the organization. In addition, the enforcement should be together with Knowledge Management (Clegg, Pitsis, Rura-Polley \& Marosszeky, 2002); strictly validate whether the LFM was in actuality prepared in a tight technique or not, brand LFM as presentation tool during budget screening and enforce LFM as tool for project appraisal and evaluation. The format to be in the field of SPPII or utilizing Log frame 3.1 software to standardize the adoption of LFM in Malaysian Government project planning. It is recommended that the process in preparing LFM be simplified.

\section{CONCLUSIONS}

This study identified gaps that exist in LFM implementation in Malaysian Government project planning throughout the ten (10) years of its implementation. The results also shown the frequent failings (logic-less frames, lack-frames and jamming) of LFM prepared by the Ministry / Agency. Existing challenges in preparing the LFM have been reaffirmed in the study where the ten (10) practical issues (getting consensus, clear objectives, level of detail, developing indicators, unrealistic target, source of verification, box filling requirement, management influence, pre-set format, limitation of time) extracted from literature review were validated in the context of Malaysian Government project planning. New practical issues (knowledge, skilled officer and experience) that emerged in this study also determined the challenges in preparing the LFM in Malaysian Government project planning.

The findings of the study also revealed that the practical issues encountered by the planning officers especially on the LFM Structure (Format) is as a result of several issues like limitation of time, box filling requirement and pre-set format, which were regarded by informants to be most significant issues that influence the quality of the LFM. From the discussion made in the previous section, it is clear that the occurrences of existing challenges which are the practical issues encountered by the planning officers are interrelated in determining the level of comprehensiveness (level of box filling) of LFM for both physical and non-physical project. The findings also suggested that knowledge management is one of the most important measures to overcome the existing challenges in preparing the LFM, followed by enforcement and format respectively.

\section{REFERENCES}

Badu, E., Owusu-Manu, D. G., Edwards, D. J., Adesi, M., \& Lichtenstein, S. (2013). Rural infrastructure development in the Volta region of Ghana: barriers and interventions. Journal of financial management of Property and Construction, 18(2), 142-159.

Bakewell, O., \& Garbutt, A. (2005). The Use and Abuse of the Logical Framework Approach: A Review of International Development NGOs’ Experiences. Stockholm: Swedish International Development Agency.

Bloomberg, L. D., \& Volpe, M. (2012). Completing your qualitative dissertation: A road map from beginning to end. Thousand Oaks: SAGE Publications.

Boyd, C.O. (2001). Phenomenology the method. In P.L. Munhall (Ed.), Nursing research: A qualitative perspective (3rd. ed., pp. 93-122). Sudbury, MA: Jones and Bartlett.

Buttigieg, S.C., Dey, P.K. and Cassar, M.R. (2016), “Combined quality funtion deployment and the logical framework approach to improve quality of emergency care in Malta”, International Journal of Health Care Quality Assurance, Vol. 29 No. 2, pp. 123-140.

Chuang, C. H., Jackson, S. E., \& Jiang, Y. (2016). Can knowledge-intensive teamwork be managed? Examining the roles of HRM systems, leadership, and tacit knowledge. Journal of management, 42(2), 524-554. 
Clegg, S. R., Pitsis, T. S., Rura-Polley, T., \& Marosszeky, M. (2002). Governmentality matters: designing an alliance culture of inter-organizational collaboration for managing projects. Organization Studies, 23(3), 317-337.

Cooper, D. R., \& Schindler, P. S. (2014). Business research methods(12th ed.). Boston: McGraw-Hill/Irwin.

Costello, G. J., Donnellan, B., \& Curley, M. (2013). A Theoretical Framework to Develop a Research Agenda for Information Systems Innovation. CAIS, 33, 26.

Couillard, J., Garon, S., \& Riznic, J. R. (2009). The Logical Framework Approach-Millennium. Project Management Journal, 40(4), 31-44. doi: http://dx.doi.org/10.1002/pmj.20117.

Cracknell, B. (1989). Evaluating the effectiveness of the Logical Framework system in practice. Project Appraisal, 4(3), 163-167.

Creswell, J. W., \& Creswell, J. D. (2018). Research design: Qualitative, quantitative, and mixed methods approaches (5th ed.). Los Angeles: SAGE.

Crawford, P., \& Bryce, P. (2003). Project monitoring and evaluation: a method for enhancing the efficiency and effectiveness of aid project implementation. International journal of project management, 21(5), 363-373.

Dale, R. (2002). Development Planning: Concepts and Tools for Planners, Managers and Facilitators. Pathumthani: Asian Institute of Technology.

Daniel P. \& Dearden P.N. (May, 2001). Integrating a Logical Framework Approach to planning into the Health Action Zone initiative. Paper presented at the CIDT/CASR University of Wolverhampton Conference Participation and Empowerment: Learning Lessons from North and South.

Denzin, N. K., \& Lincoln, Y. S. (2018). Introduction: The discipline and practice of qualitative research. In N. K. Denzin \& Y. S. Lincoln (Eds.), The Sage handbook of qualitative research (5th ed., pp. 1-19). Thousand Oaks, CA: Sage.

Dvir, D., Lechler, T. (2004). Plans are nothing, changing plans is everything: the impact of changes on project success. In Research Policy, 33 (1), 1-15.

Economic Plan Unit (EPU) (2009). Guideline for Planning and Preparation of Programs and Projects Development. Malaysia, Putrajaya: Author.

Economic Plan Unit (EPU) (2010). Handbook for Logical Framework Approach. Malaysia, Putrajaya: Author.

Economic Plan Unit (EPU) (2015). Eleventh Malaysia Plan, 2016-2020 (11th MP): Anchoring Growth on, 1(9), 21-22, Malaysia, Putrajaya: Author.

El Asmar, M., Hanna, A.S. and Loh, W. (2016), "Evaluating integrated project delivery using the project quarterback rating", Journal of Construction Engineering and Management, Vol. 142 No. 1, pp. 1-13.

Elie G.A., Caesar A.S., Arindam C., Irtishad A. (2019). Integrated Project Delivery Implementation Framework for Water and Wastewater Treatment Plant Projects. Engineering, Construction and Architectural Management, DOI 10.1108/ECAM-02-2019-0075

Elo, S., \& Kyngäs, H. (2008). The qualitative content analysis process. Journal of advanced nursing, 62(1), 107115.

Etikan, I., Musa, S. A., \& Alkassim, R. S. (2016). Comparison of Convenience Sampling and Purposive Sampling. American Journal of Theoretical and Applied Statistics, 5(1), 1. doi:10.11648/j.ajtas.20160501.11

European Integration Office. (2011). Guide to the Logical Framework Approach. Belgrade, Republic of Serbia: Europe. Global Print. 
Fonteyn, M. E., Vettese, M., Lancaster, D. R., \& Bauer-Wu, S. (2008). Developing a codebook to guide content analysis of expressive writing transcripts. Applied Nursing Research, 21(3), 165-168.

Gasper, D. (1999): Problems in the Logical Framework Approach and Challenges for "Project Cycle Management". In: the Courier, No. 173, January - February 1999, p. 75 - 77.

Gasper, D. (2000). Evaluating The Logical Framework Approach Towards Learning-Oriented Development Evaluation. Public Adminitsration and Development, 20, 17-28.

Gasper, D. (2000). "Logical Frameworks": Problems and Potentials. Institute of Social Studies.

Golini, R., Landoni, P., \& Kalchschmidt, M. (2018). The adoption of the logical framework in international development projects: a survey of non-governmental organizations. Impact Assessment and Project Appraisal, 36(2), 145-154.

Goodstadt, L.F. (2005). Uneasy partners: The conflict between public interest and private profit in Hong Kong (Vol. 1). Hong Kong University Press.

Hamid A. and Carrie S. D. (2019). Restructuration of Architectural Practice in Integrated Project Delivery (IPD): Two Case Studies. Engineering, Construction and Architectural Management Vol. 26 No. 1, 2019 pp. 104-117

Ika, L.A., \& Lytvynov, V. (2011). The "management-per-result" approach to international development project design. Project Management Journal, 42(4), 87-104.

Implementation and Coordination Unit (ICU) (2012). General Current Letter 1/2012: Guidelines of Program / Project Development Achievement through Outcome Assessment. Malaysia, Putrajaya: Author.

Implementation and Coordination Unit (ICU) (2017). Outcome Assessment Committee Meeting(JKPO): Exit Conference Report. Paper presented at the JKPO 2016 Exit Conference on 8th February 2017.

Jaapar, A., Maznan, N.A., Zawawi, M. (2012). Implementation of Value Management in Public Projects. In Procedia - Social and Behavioral Sciences, 68, 77-86.

Kothari, C.R. (2004). Research methodology methods \& techniques. New Delhi: New Age International (P).

Las Casas, G., \& Scorza, F. (2016, July). Sustainable planning: a methodological toolkit. In International Conference on Computational Science and Its Applications (pp. 627-635). Springer, Cham.

MacQueen, K., McLellan, E., Kay, K., \& Milstein, B. (1998). Codebook development for team-based qualitative analysis. Cultural Anthropology Methods, 10(2), 31-36.

Mason, J. (1996). Qualitative researching. Thousand Oaks, CA: Sage.

Mayring, P. (2002). Einführung in die qualitative Sozialforschung, Eine Anleitung zu qualitativem Denken (5th ed.). Weinheim: Beltz

Michalak, J. M., \& Ristino, R. J. (2013). Phenomenological study of employee perceptions of managerial behaviors as personal enactments of organizational culture. Journal of Intercultural Management, 5(3), 63-73.

Miles, M. B., Huberman, A. M., \& Saldana, J. (2014). Qualitative Data Analysis: A Methods Sourcebook. Thousand Oaks, CA: Sage.

Murphy, D., Baker, N., \& Fisher, D. (1974). Determinants of Project Success. Boston College, National Aeronautics and Space Administration. 
Nuthu, L.M. (2013). Evaluation of Logical Framework Approach and Its Effect on Stakeholder Participation in the Design and Execution of Projects (A Case of Economic Stimulus Programmes In Nairobi County (Master's thesis, Kenyatta University). Retrieved from http://ir-library.ku.ac.ke/handle/123456789/11259.

Nadler, J., Thompson, L., \& Boven, L. V. (2003). Learning negotiation skills: Four models of knowledge creation and transfer. Management Science, 49(4), 529-540.

Nam Nguyen, H., \& Mohamed, S. (2011). Leadership behaviors, organizational culture and knowledge management practices: An empirical investigation. Journal of Management Development, 30(2), 206221.

Nonaka, I., \& Konno, N. (1998). The concept of "Ba": Building a foundation for knowledge creation. California management review, 40(3), 40-54.

Nonaka, I., \& Takeuchi, H. (1995). The knowledge-creating company: How Japanese companies create the dynamics of innovation. Oxford university press.

Ortengren, K., (n.d.), Project Planning according to the LFA-method, Sweedish International Centre for Local Democracy.

Patton, M.Q. (1999). Enhancing the quality and credibility of qualitative analysis. Health Sciences Research, 34, 1189-1208.

Pinto, J.K. \& Slevin, D.P. (1987). Critical factors in successful project implementation. IEEE Transactions Engineering Management, 34(1), 22-27.

Practical Concepts (1978). The logical framework: A manager's guide to a scientific approach to design and evaluation. Washington, DC: Author.

Radujkovic, M., \& Sjekavica, M. (2017). Project Management Success Factors. In Procedia Engineering, 196, 607-615.

Sandra, C. B., Dorothy, G. and Prasanta, D. (2016). Continuous quality improvement in a Maltese hospital using logical framework analysis. Journal of Health Organization and Management Vol. 30 No. 7, 2016 pp. 1026-1046

Sartorius, R. (1996). The third generation logical framework approach: Dynamic management for agricultural research projects. Journal of Agricultural Education and Extension, 2(4), 49-62.

Tongco, M. D. C. (2007). Purposive sampling as a tool for informant selection. Ethnobotany Research and applications, 5, 147-158.

Wiggins, S. \& Shields, D. (1995). Clarifying the 'logical framework' as a tool for planning and managing development projects. Project Appraisal, 10(1), 2-12.

World Bank. (2005). The Logframe Handbook. Washington, DC: Author. 